\title{
Characterization of Three Human Apolipoprotein E Isoforms (E2, E3 and E4) Expressed in Escherichia coli
}

\author{
Anne Barbier ${ }^{1}$, Athanase Visvikis ${ }^{1}$, Florence Mathieu ${ }^{1}$, Laurent Diez ${ }^{1}$, Louis M. Havekes ${ }^{2}$ and Gérard Siest ${ }^{1}$ \\ ${ }^{1}$ Centre du Médicament, Université de Nancy 1 H. Poincaré, URA CNRS 597, Nancy, France \\ ${ }^{2}$ Gaubius Laboratory TNO-PG, Leiden, The Netherlands
}

Summary: Apolipoprotein $\mathrm{E}$ is one of the apolipoproteins involved in cholesterol metabolism. Three major isoforms are present in men: E2, E3, E4 corresponding to the products of three alleles. They have different affinities for receptors and the $\varepsilon 4$ allele is a risk factor for cardiovascular diseases and more recently for Alzheimer's disease. We describe here the production, by heterologous expression in Escherichia coli, of the three apolipoprotein $\mathrm{E}$ isoforms for use in both research and clinical laboratories. By Surface Plasmon Resonance, the purified recombinant apolipoprotein $\mathrm{E}$ isoforms were able to recognize three monoclonal anti-human apolipoprotein $\mathrm{E}$ antibodies with affinity constants close to those of purified human apolipoprotein E. For receptor binding studies, the recombinant apolipoprotein $\mathrm{E}$ isoforms were associated with VLDL isolated from apolipoprotein $\mathrm{E}$ knockout mice. Although the association of the recombinant apolipoproteins E with the mouse VLDL was less efficient than that of human plasma apolipoprotein E3, the recombinant apolipoprotein E3 and apolipoprotein E4 complexes competed efficiently with ${ }^{125}$ I-labelled LDL for binding to the LDL receptor in J774 macrophages, whereas the recombinant apolipoprotein E2-VLDL complexes did not. These results suggest that the recombinant apolipoprotein $\mathrm{E}$ isoforms have biological properties similar to the human apolipoprotein $\mathrm{E}$ isoforms.

\section{Introduction}

Apolipoprotein $\mathrm{E}$ is a component of several classes of lipoproteins that serve as lipid transport particles in human plasma and body fluids (1). Apolipoprotein E is synthesized with an 18 amino acid signal peptide that is cleaved cotranslationally (2). The resulting 299 amino acid protein is a secretory glycoprotein expressed by a variety of tissues, essentially liver parenchymal cells, but also macrophages, adrenal glands and astrocytes in the brain where it has been shown to be the major apolipoprotein $(3,4)$. The protein is secreted in a highly sialylated form but is then processed to its plasma state in which $80 \%$ of the protein is desialylated (3).

Human apolipoprotein $\mathrm{E}$ is polymorphic. This polymorphism stems from three common alleles $\varepsilon 2, \varepsilon 3$ and $\varepsilon 4$ (5). Three homozygous phenotypes (apolipoprotein $\mathrm{E} 2 / \mathrm{E} 2, \mathrm{E} 3 / \mathrm{E} 3$ and E4/E4) and three heterozygous phenotypes (apolipoprotein E3/E2, E3/E4 and E4/E2) arise from the expression of any two of the alleles. In the Caucasian population the prevalence is: apolipoprotein E2/E2 $1 \%$, apolipoprotein E3/E3 $60 \%$, apolipoprotein E4/E4 $3 \%$, apolipoprotein E3/E2 $12 \%$, apolipoprotein E3/E4 23\% and apolipoprotein E4/E2 2\% (6). apolipoprotein E4 and apolipoprotein E2 differ from apolipoprotein E3 by one of two point mutations resulting in Cys/Arg interchanges $\left(\mathrm{Cys}^{112} \rightarrow\right.$ Arg for apolipoprotein $\mathrm{E} 4$ and $\operatorname{Arg}^{158} \rightarrow$ Cys for apolipoprotein E2).

Apolipoprotein $\mathrm{E}$ also plays a role in immunoregulation and is implicated in the regeneration of the sciatic nerve where it is synthesized by macrophages (7). Apolipoprotein $\mathrm{E}$ is a ligand for several receptors: the apolipoprotein (B/E) low density lipoprotein receptor (LDL receptor), the LDL receptor-related protein (LRP), as well as the VLDL receptor, lipolysis-stimulated receptor (LSR) and a newly described apolipoprotein $E$ receptor $2(3,8-10)$. The loss of $\operatorname{Arg}^{158}$ in the apolipoprotein E2 isoform results in a loss of the capacity of apolipoprotein $\mathrm{E}$ to bind to the LDL receptor, and subjects developing type III hyperlipoproteinaemia often present the $\varepsilon 2 / \varepsilon 2$ phenotype $(11,12)$. Apolipoprotein E4 is a risk factor for coronary diseases because of its direct increasing effect on cholesterol levels (13).

Compelling evidence has recently implicated apolipoprotein $\mathrm{E}$ in the development of Alzheimer's disease (14). There is a dose-response relationship between the $\varepsilon 4$ allele and the occurrence of late onset Alzheimer's disease: $\varepsilon 4$ homozygosity is a major risk factor for $\mathrm{Alz}$ heimer's disease (15). There is a link between apolipoprotein E4 and early development of the disease and an increased number of senile plaques and fibrillary deposits $(16,17)$. In contrast, apolipoprotein E2 would be a longevity factor and seems to play a protective role in Alzheimer's disease $(18,19)$. 
Because of the implication of particular apolipoprotein E genotypes in cardiovascular or neurodegenerative diseases, we reasoned that the gene product could be involved and we decided to produce large quantities of these proteins for various applications, including the production of a reference material. Such a standard is necessary for developing a reference method suitable in both research and clinical laboratories worldwide.

This report describes the development of an expression system to produce the three apolipoprotein $\mathrm{E}$ isoforms in $E$. coli and the subsequent characterization of the recombinant fusion proteins. Compared to the other apolipoprotein E expression systems previously described in bacteria, ours is able to produce large amounts of recombinant apolipoprotein $\mathrm{E}$ that could be easily purified. The first one described in the literature (27) provided some apolipoprotein $\mathrm{E}$ that was rapidly proteolyzed, and more recently, another system expressing apolipoprotein $E$ in the periplasm (28) had a very low level of production of the recombinant protein. The major advantage of our expression system is the single-step purification of the recombinant apolipoprotein $\mathrm{E}$. The purification of the recombinant protein expressed in all other expression systems, as the purification of the human plasma apolipoprotein E, requires several chromatographic steps. The plasma human apolipoprotein E purification needs the isolation of human very low density lipoproteins (VLDL) and several steps of delipidation before the affinity and gel filtration chromatography. In addition our expression system overcomes the extreme difficulties in obtaining more rare phenotypes in the human population such as apolipoprotein E4 and apolipoprotein E2. In contrast to purification after plasmapheresis, our system permits the isolation of purified protein without contamination with other apolipoproteins (apolipoprotein B, apolipoprotein C). E. coli allowed a very rapid inexpensive method for obtaining a high amount of recombinant apolipoprotein $\mathrm{E}$ that was purified with a high degree of purity. We have described separately some physicochemical properties of the recombinant apolipoprotein E3 and apolipoprotein E4 (20).

One of our aims is to compare the different properties of the three isoforms, particularly their conformation, to establish the molecular basis of the difference in reactivity and/or metabolism of the three isoforms, and to understand their involvement in neurodegenerative diseases in order to elucidate the potential protective role of apolipoprotein E2 and the role of apolipoprotein E4 as a risk factor in Alzheimer's disease.

To assess their immunological characteristics, we quantitatively measured the binding of three anti-human apolipoprotein E monoclonal antibodies (21) to plasma apolipoprotein E3 and recombinant apolipoprotein E isoforms (apolipoprotein E2, E3 and E4) by Surface
Plasmon Resonance (SPR). Surface Plasmon Resonance detection allows the quantitative real-time measurement of binding interactions between immobilized and solution-phase ligands without radiolabelling or biochemical tagging. The biological activity of the recombinant material was also investigated by testing the LDL-receptor binding activity of apolipoprotein E enriched VLDL preparations in macrophages.

\section{Materials and Methods}

\section{Materials}

Specific products were from the following suppliers: Taq DNA polymerase from Boehringer Mannheim (Germany), [ $\alpha-{ }^{32}$ P]dATP $(29.6 \mathrm{TBq} / \mathrm{mmol}=800 \mathrm{mCi} / \mathrm{mmol})$ and autoradiography films from Dupont Nemours (USA), restriction enzymes from Boehringer Mannheim (Germany) and Promega (Madison, USA), nucleotides, apolipoprotein E-specific oligonucleotides for amplification by polymerase chain reaction, apolipoprotein E4 and apolipoprotein E2 specific oligonucleotides for mutagenesis, M13 reverse sequencing primer, pARHS2, 5-bromo-4-chloro-indolyl- $\beta$ - $D$-galactopyranoside (XGal), and isopropyl- $\beta-D$-thiogalactopyranoside (IPTG) from Eurogentec (Belgium), ProBond Gel, TA cloning kit and pRSETB from Invitrogen (San Diego, USA), E. coli BL21(DE3) competent cells from Novagen (Madison, USA), HBS buffer $(0.010 \mathrm{~mol} / 1 \mathrm{HEPES} \mathrm{pH} 7.4,0.15 \mathrm{~mol} / \mathrm{l} \mathrm{NaCl}, 0.0034 \mathrm{~mol} / 1$ EDTA, $50 \mu \mathrm{l} / 1$ surfactant P20), amine coupling kit $(0.1 \mathrm{~mol} / 1 \mathrm{~N}-$ hydroxysuccinimide, $0.4 \mathrm{~mol} / \mathrm{l}$ N-ethyl-N'-(diethylaminopropyl) carbodiimide and $1.0 \mathrm{~mol} / 1$ ethanolamine hydrochloride, $\mathrm{pH} 8.5$ ) were obtained from Pharmacia, Biosensor (Sweden), T7 sequencing kit and oligo $(\mathrm{dT})_{12-18}$ for reverse transcription, molecular mass markers from Pharmacia Biotech (Sweden), Altered Sites ${ }^{\mathrm{TM}}$ in vitro Mutagenesis System, M-MLV reverse transcriptase and RNasine from Promega (Madison, USA), LB, LB agar, ampicillin, carbenicillin, kanamycin, dimethylsulphoxide and dithiothreitol from Sigma (Missouri, USA).

\section{Construction of different cDNAs}

The cloning of apolipoprotein E3 and apolipoprotein E4 cDNA has been previously described (21). The apolipoprotein E2 sequence for expression in Escherichia coli was derived by polymerase chain reaction from the mutated sequence of apolipoprotein E2 obtained by direct mutagenesis of the cDNA of apolipoprotein $\mathrm{E} 3$ and cloned into the eukaryotic pcDNAIneo vector (Barbier, unpublished). Amplifications were from pcDNAIneo-apolipoprotein $\mathrm{E} 2$ using oligonucleotides 5'GATCCCATGGCTAAGGTGGAGCAAGCGGTGGAG3' as 5 ' primer and 5'GATCAAGCTTCAGTGATTGTCCCTGGG$\mathrm{CAC} 3^{\prime}$ as $3^{\prime}$ primer (underlined sequences correspond to the restriction sites Nco I and Hind III respectively). The reaction contained $15 \mathrm{ng}$ pcDNAIneo-apolipoprotein E2 in $0.075 \mathrm{~mol} / \mathrm{l} \mathrm{Tris}-\mathrm{HCl} \mathrm{pH}$ $9.0,0.020 \mathrm{~mol} / 1\left(\mathrm{NH}_{4}\right)_{2} \mathrm{SO}_{4}, 100 \mathrm{mg} / 1$ Tween 20 buffer supplemented with $0.002 \mathrm{~mol} / 1 \mathrm{MgCl}_{2}, 0.2 \mathrm{mmol} / \mathrm{l}$ of each $\mathrm{dNTP}, 0.001$ $\mathrm{mmol} / \mathrm{l}$ of each primer, $50 \mathrm{ml} / 1$ dimethylsulphoxide, $2 \mathrm{U}$ Taq DNA polymerase. After an initial denaturation step for 6 minutes at $96^{\circ} \mathrm{C}$, amplification was achieved with the following program: $1 \mathrm{~min}$ at $96^{\circ} \mathrm{C}, 2 \mathrm{~min}$ at $60^{\circ} \mathrm{C}, 3 \mathrm{~min}$ at $72{ }^{\circ} \mathrm{C}, 16$ cycles. The PCR product was first cloned in the pCRII vector using the TA cloning kit. The integrity of these new sequences was confirmed by DNA sequencing. The cDNAs were then subcloned in $\mathrm{pRSETB}$ expression vectors between Nco I/Hind III restriction sites from which they were recovered by $N d e \mathrm{I} / H$ ind III restriction digestion and subsequent cloning into the same sites of the modified pARHS2 vectors.

\section{Bacterial expression systems}

The pRSETB vector allows the cytoplasmic expression of the complete apolipoprotein E sequence in fusion with a $M_{\mathrm{r}} 4000$ aminoterminal peptide that contains a poly-His stretch. This plasmid is under the control of the strong T7 promoter. 
pARHS2 expresses the same protein as pRSETB. This very stable plasmid is under the control of the T7 promoter and contains the hok/sok system (hok = host killing, sok = suppression of killing), which leads to cell death for plasmid free cells.

For the expression of the apolipoprotein E sequence pRSETB-apolipoprotein E3 and pARHS2-apolipoprotein E3, -apolipoprotein E2 and -apolipoprotein $\mathrm{E} 4$ need to be introduced into an $E$. coli (DE3) strain $\left(\mathrm{F}^{-}\right.$, omp $\operatorname{Tr}_{\mathrm{B}}^{-}, \mathrm{m}_{\mathrm{B}}^{-}, \lambda(\mathrm{DE} 3)$ ) (22) that carries the $\mathrm{T} 7 \mathrm{RNA}$ polymerase gene under the control of the lacUV5 promoter. The BL21 E. coli strain provides an excellent background for expression of recombinant protein since it lacks lon and ompT proteases.

\section{Stability of the expression vectors}

To study the stability of the recombinant plasmid, DE3 lysogens that carried the plasmid conferring ampicillin resistance were titered on four plates containing $0.1 \mathrm{~g} / 1$ ampicillin, $0.001 \mathrm{~mol} / 1$ isopropyl- $\beta-D$-thiogalactopyranoside (IPTG), both or neither. The plasmid stability was followed throughout the production: saturated primary culture, $t_{0}$ : time of induction, $t_{0}+1 \mathrm{~h}, \mathrm{t}_{0}+3 \mathrm{~h}, \mathrm{t}_{0}+5 \mathrm{~h}$ : one hour, three hours and five hours after induction respectively and one growth curve for the $E$. coli strain was established. One $\mathrm{ml}$ of culture was diluted to an $\mathrm{A}_{600}$ of $10^{-5}$, then $50 \mu \mathrm{l}$ were plated on four different plates containing $0.1 \mathrm{~g} / 1 \mathrm{ampicillin}$, or $0.001 \mathrm{~mol} / \mathrm{l}$ isopropyl- $\beta-D$-thiogalactopyranoside (IPTG) or both or with neither component. The percentage of cells on the plate/number of viable cells was calculated.

\section{Production and purification}

E. coli BL21(DE3) strains carrying pRSETB-apolipoprotein E3, pARHS2-apolipoprotein E3, pARHS2-apolipoprotein E2 or pARHS2-apolipoprotein E4 were grown overnight at $37^{\circ} \mathrm{C}$ in Luria-Bertani (LB) medium containing $0.1 \mathrm{~g} / 1$ ampicillin and then diluted 100 -fold into LB-ampicillin medium and grown to a cell density $\mathrm{A}_{600}$ of 0.6 . Then $0.001 \mathrm{~mol} / 1$ isopropyl- $\beta$ - $D$-thiogalactopyranoside (IPTG) was added and the culture was grown further for 2 to 24 hours. Bacteria from 1 litre of culture were harvested by centrifugation $\left(1000 \mathrm{~g}, 10 \mathrm{~min},+4^{\circ} \mathrm{C}\right)$ and the pellet was resuspended in $40 \mathrm{ml}$ of $0.02 \mathrm{~mol} / 1 \mathrm{Tris}-\mathrm{HCl}, 0.1 \mathrm{~mol} / \mathrm{l} \mathrm{NaCl}$. Lysozyme $\left(15 \mathrm{~g} / 1\right.$ in $\left.\mathrm{H}_{2} \mathrm{O}\right)$ was added to a final concentration of 0.75 $\mathrm{g} / 1$ and the sample was incubated at room temperature for $30 \mathrm{~min}$ utes. Cells were lysed by sonication ( 5 bursts, $40 \mathrm{~W}, 10 \mathrm{~s} / \mathrm{burst}$ ) on ice. RNase and DNase were added to a final concentration of 0.001 $\mathrm{g} / \mathrm{l}$ and $0.025 \mathrm{~g} / \mathrm{l}$, respectively, and the sample was incubated for $30 \mathrm{~min}$ at room temperature. After centrifugation $(20000 \mathrm{~g}, 15 \mathrm{~min}$, $+4{ }^{\circ} \mathrm{C}$ ) the pellet was resuspended in $40 \mathrm{ml}$ of $0.020 \mathrm{~mol} / 1$ Tris$\mathrm{HCl}, 0.1 \mathrm{~mol} / 1 \mathrm{NaCl}$ containing $1 \mathrm{~g} / 1$ Triton $\mathrm{X}-100$ and stirred at room temperature for $30 \mathrm{~min}$. Insoluble material was removed by centrifugation $\left(20000 \mathrm{~g}, 15 \mathrm{~min},+4{ }^{\circ} \mathrm{C}\right)$ and the soluble proteins were precipitated by addition of acetone (final volume fraction 0.6 ) and recovered by centrifugation $\left(20000 \mathrm{~g}, 15 \mathrm{~min},+4{ }^{\circ} \mathrm{C}\right)$. The pellet was resuspended in $40 \mathrm{ml}$ of $6 \mathrm{~mol} / \mathrm{l}$ guanidine- $\mathrm{HCl}, 0.20$ $\mathrm{mol} / 1$ sodium phosphate buffer $\mathrm{pH} 7.8,0.5 \mathrm{~mol} / 1 \mathrm{NaCl}$ and stirred overnight at $+4{ }^{\circ} \mathrm{C}$. After centrifugation $(20000 \mathrm{~g}, 15 \mathrm{~min}$, $+4{ }^{\circ} \mathrm{C}$ ), the supernatant was filtered through a $0.22 \mu \mathrm{m}$ filter and loaded on a Ni-Gel (ProBond gel) column that was previously equilibrated with a $0.20 \mathrm{~mol} / 1$ phosphate buffer at $\mathrm{pH} 7.8$ containing $6 \mathrm{~mol} / 1$ urea, $0.15 \mathrm{~mol} / 1 \mathrm{NaCl}$. Two washing steps were performed: first with the equilibration buffer $\mathrm{pH} 7.8$ to remove unbound material, then with the same buffer at $\mathrm{pH} 6.0$. The elution was finally performed with the same buffer at $\mathrm{pH} 4.0$. The fractions were dialyzed extensively against $0.1 \mathrm{~mol} / 1$ ammonium bicarbonate, aliquoted and stored at $-80^{\circ} \mathrm{C}$.

Human apolipoprotein E3 was purified from human plasma very low density lipoproteins of normal $\varepsilon 3 / \varepsilon 3$ individuals as previously described (23).

Characterization of recombinant human apolipoprotein E isoforms by Surface Plasmon Resonance analysis

The analysis was performed on a BIAlite ${ }^{\mathrm{TM}}$ apparatus (Pharmacia Biosensor, Sweden) using Surface Plasmon Resonance (24). Sur- face Plasmon Resonance uses an optical method to detect changes in the refractive index within a thin dextran matrix. The binding of a soluble protein to an immobilized ligand increases the protein concentration within the matrix. This alters the refractive index within the matrix and this change is quantified in resonance units (R.U.). The response directly correlates with the bound ligand mass.

\section{Preparation of the sensorchip surface}

During immobilization, the flow rate was maintained at $5 \mu \mathrm{l} / \mathrm{min}$. The surface of the CM5 sensorchip was activated by injecting $35 \mu \mathrm{l}$ of a mixture of $0.1 \mathrm{~mol} / 1 \mathrm{~N}$-ethyl-N'-(diethylaminopropyl)carbodiimide/ $0.4 \mathrm{~mol} / \mathrm{l} \mathrm{N}$-hydroxysuccinimide $(1+1$ by vol.). Then $35 \mu \mathrm{l}$ of $0.01 \mathrm{~g} / 1$ apolipoprotein $\mathrm{E}$ in $0.01 \mathrm{~mol} / \mathrm{l}$ sodium acetate $(\mathrm{pH} 4.0)$ were injected followed by $20 \mu \mathrm{l}$ of $4 \mathrm{~mol} / \mathrm{l}$ guanidine- $\mathrm{HCl}, 0.01$ $\mathrm{mol} / \mathrm{l}$ Tris, $\mathrm{pH}$ 8.0. The surface was saturated by injection of $35 \mu \mathrm{l}$ of $1.0 \mathrm{~mol} / \mathrm{l}$ ethanolamine hydrochloride, $\mathrm{pH} 8.5$. This method immobilizes the ligand via the primary amino groups. Since 1000 resonance units (R. U.) determined by Surface Plasmon Resonance correspond to $1.0 \mathrm{pg} / \mathrm{mm}^{2}$ of bound ligand, the total immobilized mass of apolipoprotein $\mathrm{E}$ under these conditions was: human plasma apolipoprotein $\mathrm{E} 3=7.5 \mathrm{pg} / \mathrm{mm}^{2}$, recombinant apolipoprotein $\mathrm{E} 3=3.53 \mathrm{pg} / \mathrm{mm}^{2}$, recombinant apolipoprotein $\mathrm{E} 4=4.5 \mathrm{pg} /$ $\mathrm{mm}^{2}$, recombinant apolipoprotein E2 $=4.45 \mathrm{pg} / \mathrm{mm}^{2}$.

\section{Kinetic analysis of monoclonal antibody binding to} apolipoprotein $E$

Stock solutions of each of the antibodies were diluted in running buffer (HBS buffer, see "Materials") to a final concentration of $40-1000 \mathrm{nmol} / \mathrm{l}$. For the binding experiments $20 \mu \mathrm{l}$ of antibody were injected at a constant flow rate of $5 \mu \mathrm{l} / \mathrm{min}$ (contact time $-4 \mathrm{~min}$ ). The antigen/monoclonal antibody dissociation was followed for $5 \mathrm{~min}$. The sensorchip surfaces were regenerated with $2 \mathrm{~mol} / \mathrm{l}$ of formic acid ( 14 to $20 \mu \mathrm{l}$, depending on the experiment). Data for the association and the dissociation phases were collected and evaluated to determine the association and dissociation rate constants with the Biaevaluation 2.1 software provided by the manufacturer (25). All determinations were performed at $25^{\circ} \mathrm{C}$.

A kinetic analysis of the sensorgrams obtained from the interaction of a monoclonal antibody with an immobilized apolipoprotein $\mathrm{E}$ was based on the following equation (25):

$$
\mathrm{dR} / \mathrm{dt}=k_{\text {ass }} \mathrm{C} \mathrm{R}_{\max }-\left(k_{\text {ass }} \mathrm{C}+k_{\text {diss }}\right) \mathrm{R}
$$

where

$R$ is the plasmon resonance-response unit (R.U.) due to the interaction of the monoclonal antibody with apolipoprotein $E$ in the surface,

$k_{\text {ass }}$ and $k_{\text {diss }}$ are the association $\left(1 \cdot \mathrm{mol}^{-1} \cdot \mathrm{s}^{-1}\right)$ and dissociation $\left(\mathrm{s}^{-1}\right)$ rate constants, respectively,

$\mathrm{C}$ is the molar concentration of injected monoclonal antibody and $R_{\max }$ is the R. U. response at saturation of the apolipoprotein $E$ binding sites.

It can be shown that $k_{\text {ass }}$ may be determined from the association phase of the sensorgram, i. e., the slope of a plot of monoclonal antibody concentration versus the slopes (called $k_{\mathrm{s}}$ ) of $\mathrm{dR} / \mathrm{dt}$ dependence on R.U. response (25). A second possibility for determining $k_{\text {ass }}$ is to first calculate $k_{\text {diss }}$ and then to resolve equation (1), which has now become a first order equation with one unknown value. Values for $k_{\text {diss }}$ can be calculated during the dissociation phase of the sensorgram since as $\mathrm{C} \rightarrow$ zero, the decay rate $(-d R / d t)$ gives $k_{\text {diss }}$ directly.

\section{LDL-receptor binding}

Isolation and enrichment of VLDL

Apolipoprotein E deficient VLDL were isolated by density gradient ultracentrifugation from the serum of apolipoprotein E knockout mice. Purified recombinant or purified human apolipoprotein $\mathrm{E}$ were incubated with apolipoprotein E deficient VLDL $(0.2 \mathrm{~g} / \mathrm{g}$ 
apolipoprotein E deficient VLDL protein) for 1 hour at $37^{\circ} \mathrm{C}$. The volume was corrected with phosphate buffered saline. Apolipoprotein $E$ enriched VLDL were separated from free apolipoprotein $E$ by another ultracentrifugation step. Control apolipoprotein E deficient VLDL were treated identically. After centrifugation, protein and apolipoprotein E contents were determined and the VLDL were stabilized with $10 \mathrm{~g} / 1$ of bovine serum albumin.

\section{Cell and $L D L$ receptor binding studies}

J774 Macrophages were grown in 24-well culture plates with $\mathrm{Dul}$ becco's Modified Eagle Medium/fetal calf serum, volume fraction 0.1 . Twenty hours before the experiment, the medium was changed to Dulbecco's Modified Eagle Medium/50 $\mathrm{ml} / 1$ lipid free human serum. Incubations were performed for 3 hours on melting ice in tetraplot in Dulbecco's Modified Eagle Medium/10 g/l human serum albumin. $\left.{ }^{125} \mathrm{I}\right] \mathrm{LDL}(0.01 \mathrm{~g} / \mathrm{l})$ competed with either the respective non-labelled (apolipoprotein $\mathrm{E}$ enriched) apolipoprotein $\mathrm{E}$ deficient VLDL or with non-labelled LDL $(0-0.05 \mathrm{~g} / 1)$. After incubation, cells were washed 5 times with phosphate buffered saline/ $1 \mathrm{~g} / 1$ bovine serum albumin and once with phosphate buffered saline alone. Cells were dissolved in $1 \mathrm{ml}$ of $0.2 \mathrm{~mol} / 1 \mathrm{NaOH}$. Sevenhundred $\mu$ l of the suspension was used for measurement of radioactivity, while $100 \mu \mathrm{l}$ was used for cell protein measurements. The binding expressed as a percentage of the control (without competitor) was plotted against the amount of competitor.

\section{Results}

Expression vector stability and recombinant apolipoprotein E production

To study the stability of the different vectors in the $E$. coli BL21(DE3) strain and to ascertain whether apolipoprotein E production was lethal to the cells, we titered bacteria following isopropyl- $\beta$ - $D$-thiogalactopyranoside induction on four different media: LB and LB containing ampicillin. isopropyl- $\beta$ - $D$-thiogalactopyranoside, or both. Assuming that recombinant apolipoprotein $\mathrm{E}$ is toxic,

a) all viable cells would grow on the plate without any additive;

b) only cells that retained the plasmid would grow in the presence of ampicillin;

c) only cells that had lost plasmid or mutants that had lost the ability to express the apolipoprotein $\mathrm{E}$ gene would grow in the presence of $i$ sopropyl- $\beta-D$-thiogalactopyranoside,

d) finally, only mutants that had lost the ability to express the apolipoprotein $\mathrm{E}$ gene would grow in the presence of both ampicillin and isopropyl- $\beta$ - $D$-thiogalactopyranoside.

When cultures of $E$. coli BL21(DE3)-pRSETB apolipoprotein $\mathrm{E}$ were induced by isopropyl- $\beta-D$-thiogalactopyranoside, inconsistent and non-reproducible results were observed:

a) cell death immediately after induction characterized by total plasmid loss and no production;

b) partial loss of the plasmid with slow growth of the remaining cells and low production level; c) no loss of plasmid with slow cell growth and high production level (fig. 1). In addition, the preservation at $-80^{\circ} \mathrm{C}$ of isolated producing clones resulted in a loss of production capability.

In view of these results the cDNAs of apolipoprotein $\mathrm{E}$ were subcloned into the pARHS2 expression vector. This plasmid contains the parB locus, which enhances vector stability.

The stability of the recombinant pARHS2 expression vector was studied throughout the culture. We observed that after induction by isopropyl- $\beta$ - $D$-thiogalactopyranoside, all viable cells harboured the recombinant vector (results not shown). This vector stability and the concomitant high level production of recombinant protein induced a decrease in the growth rate. After induction with isopropyl- $\beta$ - $D$-thiogalactopyranoside, recombinant E. coli BL21(DE3) cells specifically produced a protein with a $M_{\mathrm{r}}$ of 40000 , in accordance with the theoretical relative molecular mass of the recombinant apolipoprotein E. This protein reacted strongly upon immunoblotting with monoclonal anti apolipoprotein $\mathrm{E}$ antibodies, thus confirming its authenticity (fig. $2 b$ ). The production level increased during the first 5 hours of induction (figs. 2a, 2b) reaching about $80 \mathrm{mg} / 1$ ( $25 \%$ of total cell protein) as estimated by scanning of the gels. After 24 hours (fig. 2a, lane 9) the production level was much lower, probably due to cell lysis as no degradation products were visible upon immunoblotting. There were no differences in the production level and the immunological reactivity of the apolipoprotein $\mathrm{E}$ expressed in this system. Furthermore all producing clones were stable upon conservation at $-80^{\circ} \mathrm{C}$. These results suggested that the production of recombinant human apolipoprotein $E$ is not lethal to the cells when the pARHS2 vector is used.

Recombinant human apolipoproteins $\mathrm{E}$ were purified by $\mathrm{Ni}^{2+}$-chelating affinity chromatography as previously described (20). The conditions for the solubilization of the bacterial proteins have changed in order to insure a better yield of purified protein. Determination of the first eight amino acids showed that the sequence corresponded to that predicted from the vector sequence.

\section{Characterization of recombinant apolipoproteins E}

\section{Monoclonal antibody-apolipoprotein $E$ interactions studied by Surface Plasmon Resonance}

In order to confirm that the immunological properties of the recombinant apolipoproteins $\mathrm{E}$ were intact, each protein was tested for binding to several anti-human plasma apolipoprotein E monoclonal antibodies.

To analyze the interaction of monoclonal antibodies 3B7, 1D7 and 3H1 with apolipoprotein $\mathrm{E}$ isoforms, 


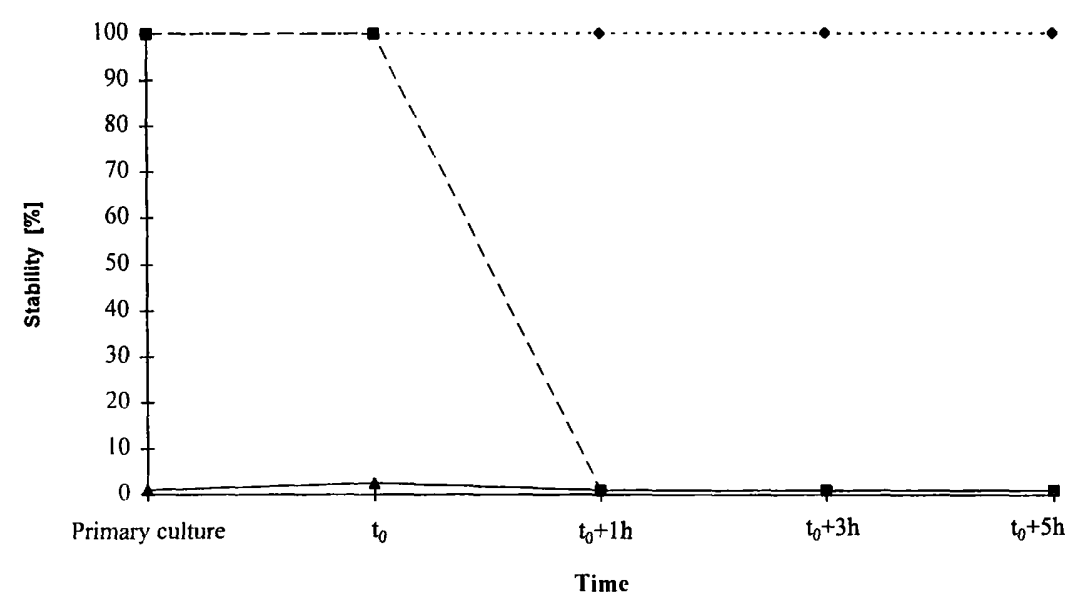

Fig. 1 Stability of the pRSETB-apolipoprotein E3 plasmid after induction by isopropyl- $\beta$ - $D$-thiogalactopyranoside.

The protein was produced by the BL21(DE3) E. coli strain in Luria-Bertani (LB) medium containing $0.1 \mathrm{~g} / 1$ ampicillin. After different times of induction with $0.001 \mathrm{~mol} / /$ isopropyl- $\beta$ - $D$-thiogalactopyranoside, aliquots were diluted to an $A_{600}=10^{-5}$. Fifty $\mu \mathrm{l}$ of diluted aliquots were grown overnight on LB, LB-ampicillin, LBisopropyl- $\beta$ - $D$-thiogalactopyranoside and LB-ampicillin-isopropyl-

$\beta$ - $D$-thiogalactopyranoside agar medium. Stability was calculated from the percentage of ampicillin-resistant colonies. The studies of the stability of the recombinant vector pRSETB-apolipoprotein E in E. coli strain showed several behaviours of this plasmid in different clones during the culture:

a) very fast total plasmid loss $(-\mathbf{\Delta}-)$,

b) partial plasmid loss (--m--) and

c) no loss of the plasmid $(\cdots \cdots)$.

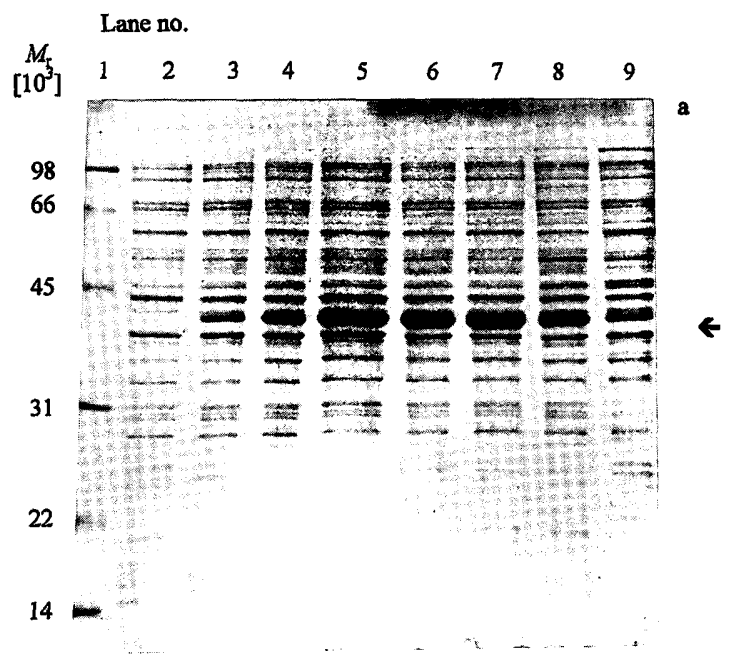

Fig. 2 Time course of the recombinant apolipoprotein E3 production with the expression plasmid pARHS2 in BL21(DE3) strain.

Total lysate from non-induced and induced cultures prepared by solubilization of the cell pellets in denaturing buffer (Sambrook et al. 1989) by heating in a boiling water bath for $3 \mathrm{~min}$. Equivalent quantities of cells were loaded on a SDS-PAGE $0.1 \%$ SDS, $12 \%$ polyacrylamide gel.

a) Proteins were stained in Coomassie Brilliant Blue. Pharmacia low molecular mass standards are shown in lane 1. Lane 2: sample at $t_{0}$ (no induction); lane $3,4,5,6,7,8,9$ : samples at $t_{0}+30$

apolipoprotein $\mathrm{E}$ isoforms (recombinant human apolipoprotein E3, apolipoprotein E2, and apolipoprotein E4 purified from $E$. coli and human plasma apolipoprotein E3) were immobilized on separate sensorchips by coupling via primary amine groups. The binding of the monoclonal antibodies to apolipoprotein $\mathrm{E}$ was measured by Surface Plasmon Resonance and the affinity and kinetic determinations were estimated using the Biaevaluation 2.1 software. As shown in figure 3a, recombinant apolipoproteins $\mathrm{E}$ bound with high affinity to the mo-

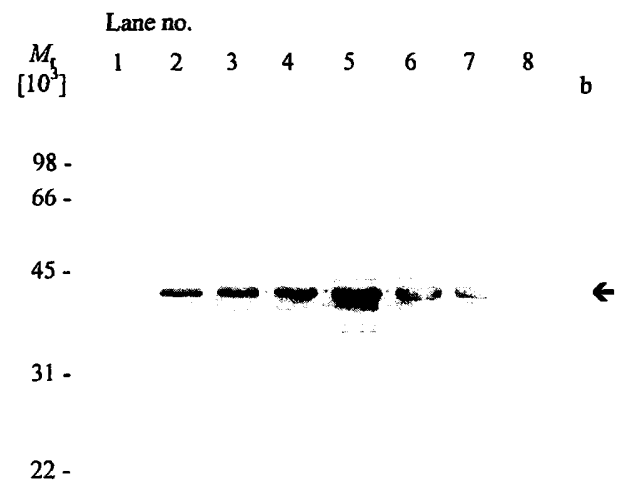

$\min ,+1 \mathrm{~h},+2 \mathrm{~h},+3 \mathrm{~h},+4 \mathrm{~h},+5 \mathrm{~h},+24 \mathrm{~h}$ after induction by isopropyl- $\beta$ - $D$-thiogalactopyranoside. The arrow indicates apolipoprotein $\mathrm{E}$.

b) The proteins from a gel equivalent to a were transferred to an Immobilon $\mathrm{P}$ membrane. Immunoblotting was performed with antihuman apolipoprotein E monoclonal antibody 1D7 and alkaline phosphatase labelled anti-mouse IgG.

Lane 1: sample at $\mathrm{t}_{0}$ (no induction); lane $2,3,4,5,6,7,8$ : samples at $t_{0}+30 \mathrm{~min},+1 \mathrm{~h},+2 \mathrm{~h},+3 \mathrm{~h},+4 \mathrm{~h},+5 \mathrm{~h},+24 \mathrm{~h}$ after induction by isopropyl- $\beta-D$-thiogalactopyranoside. The arrow indicates apolipoprotein $\mathrm{E}$.

noclonal antibodies, and these interactions were saturable and reversible. Figure $3 \mathrm{~b}$ shows that the relation between the $k_{\mathrm{s}}$ and the monoclonal antibody concentration is linear. These results indicate that the observed signals increase proportionally with the monoclonal antibody concentration thus allowing the estimation of kinetic constants. Table 1 summarizes the rate constants and the equilibrium dissociation constants $\left(k_{\text {ass }}, k_{\text {diss }}, K_{\mathrm{D}}\right.$ ) for the apolipoprotein E-antibody interactions. $k_{\text {ass }}$ is the mean of the $k_{\text {ass }}$ values defined using both methods (with 

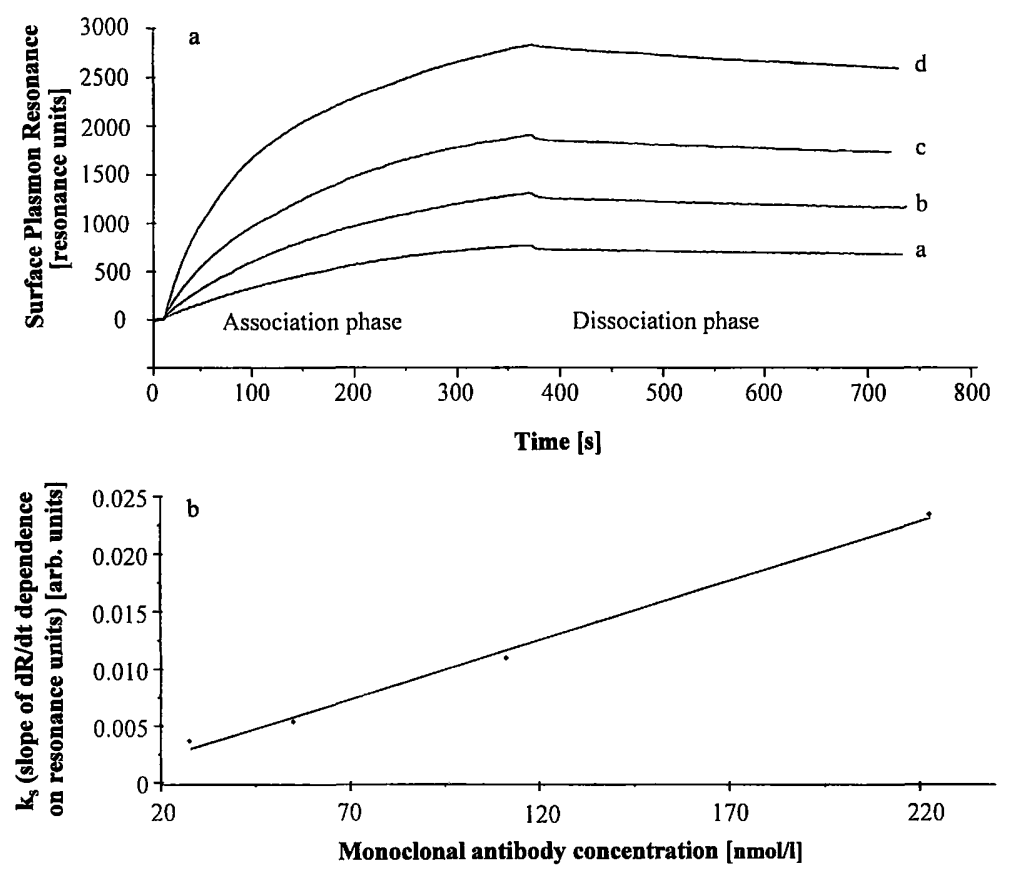

Fig. 3 Surface Plasmon Resonance analysis of the interaction between purified recombinant apolipoprotein E3 and monoclonal antibody $3 \mathrm{H} 1$.

a) Binding of monoclonal antibody (3H1) to purified recombinant apolipoprotein E3. The binding was measured as the increase in resonance units (R. U.). Curves a, b, c, d: [monoclonal antibody $3 \mathrm{H} 1]=30 \mathrm{nmol} / 1 ; 60 \mathrm{nmol} / \mathrm{l} ; 100 \mathrm{nmol} / 1$ and $220 \mathrm{nmol} / 1$, respectively.

and without calculation of $k_{\mathrm{s}}$ ). The results showed that the three monoclonal antibodies recognized the three recombinant apolipoprotein $\mathrm{E}$ isoforms similarly to plasma human apolipoprotein E3 and with close kinetic characteristics. b) Linear curve $k_{\mathrm{s}}$ versus monoclonal antibody concentration. In figure $3 \mathrm{a}$, the association phase was graphed $(\mathrm{dR} / \mathrm{dt})$ as a function of binding (R.U.), $k_{\mathrm{s}}$ was calculated as to be the slope of this graph. Then $k_{\text {ass }}$ was determined by plotted $k_{\mathrm{s}}$ versus monoclonal antibody concentration.

Slope $=k_{\text {ass }}$.

Tab. 1 Kinetic constants of the interaction between three monoclonal anti-apolipoprotein $\mathrm{E}$ antibodies and apolipoprotein $\mathrm{E}$ isoforms.

\begin{tabular}{|c|c|c|c|}
\hline \multirow[t]{2}{*}{ Apolipoprotein } & \multicolumn{3}{|l|}{ Antibodies } \\
\hline & $3 \mathrm{~B} 7$ & $3 \mathrm{H} 1$ & $1 \mathrm{D} 7$ \\
\hline Human apolipoprotein E3 & $\begin{array}{l}k_{\text {ass }}{ }^{\mathrm{a}}=5.03 \pm 0.42 \\
k_{\text {diss }}{ }^{\mathrm{b}}=1.18 \pm 0.42 \\
K_{\mathrm{D}}{ }^{\mathrm{c}}=2.35 \pm 1\end{array}$ & $\begin{array}{l}k_{\text {ass }}=10.5 \pm 0.69 \\
k_{\text {diss }}=2.13 \pm 0.25 \\
K_{\mathrm{D}}=2.02 \pm 0.21\end{array}$ & $\begin{array}{l}k_{\text {ass }}=6.08 \pm 0.46 \\
k_{\text {diss }}=6.36 \pm 0.84 \\
K_{\mathrm{D}}=10.46 \pm 1\end{array}$ \\
\hline Recombinant apolipoprotein E3 & $\begin{array}{l}k_{\text {ass }}=4.34 \pm 0.2 \\
k_{\text {diss }}=2.66 \pm 0.68 \\
K_{\mathrm{D}}=6.13 \pm 1.40\end{array}$ & $\begin{array}{l}k_{\text {ass }}=6.21 \pm 0.61 \\
k_{\text {diss }}=2.25 \pm 0.06 \\
K_{\mathrm{D}}=3.62 \pm 0.08\end{array}$ & $\begin{array}{l}k_{\text {ass }}=9.4 \pm 0.56 \\
k_{\text {diss }}=18.3 \pm 0.3 \\
K_{\mathrm{D}}=19.47 \pm 0.12\end{array}$ \\
\hline Recombinant apolipoprotein E2 & $\begin{array}{l}k_{\text {ass }}=3.5 \pm 0.45 \\
k_{\text {diss }}=2.28 \pm 1.1 \\
K_{\mathrm{D}}=6.51 \pm 3.90\end{array}$ & $\begin{array}{l}k_{\text {ass }}=5.28 \pm 1.5 \\
k_{\text {diss }}=1.34 \pm 0.20 \\
K_{\mathrm{D}}=2.54 \pm 0.94\end{array}$ & $\begin{array}{l}k_{\text {ass }}=4.69 \pm 0.81 \\
k_{\text {diss }}=7.72 \pm 1.21 \\
K_{\mathrm{D}}=16.46 \pm 1.18\end{array}$ \\
\hline Recombinant apolipoprotein E4 & $\begin{array}{l}k_{\text {ass }}=3.29 \pm 0.36 \\
k_{\text {diss }}=2.18 \pm 0.37 \\
K_{\mathrm{D}}=6.63 \pm 0.84\end{array}$ & $\begin{array}{l}k_{\text {ass }}=7.88 \pm 0.41 \\
k_{\text {diss }}=2.8 \pm 0.45 \\
K_{\mathrm{D}}=3.55 \pm 0.49\end{array}$ & $\begin{array}{l}k_{\text {ass }}=4.12 \pm 0.32 \\
k_{\text {diss }}=7.94 \pm 0.73 \\
K_{\mathrm{D}}=19.27 \pm 3.97\end{array}$ \\
\hline
\end{tabular}

Units: ${ }^{\mathrm{a}} k_{\mathrm{ass}}=10^{4} \mathrm{l} \cdot \mathrm{mol}^{-1} \cdot \mathrm{s}^{-1},{ }^{\mathrm{b}} k_{\mathrm{diss}}=10^{-4} \mathrm{~s}^{-1}$,

${ }^{\mathrm{c}} K_{\mathrm{D}}=\mathrm{nmol} / 1$

The kinetic constants $k_{\text {ass }}$ and $k_{\text {diss }}$ were calculated with the BIA evaluation 2.1 software, from the association and dissociation phases on the sensorgram obtained by Surface Plasmon Resonance. Several concentrations of each antibody (3B7, 1D7 and 3H1) in

\section{$L D L$ receptor binding studies}

The LDL receptor binding activity of the recombinant apolipoproteins E was assessed using the J774 macrophage cell line. VLDL from apolipoprotein E knockout mice were separately enriched with each of the recombi-

the range of $30-220 \mathrm{nmol} / 1$, bound to different immobilized apolipoprotein $\mathrm{E}$ (human apolipoprotein $\mathrm{E} 3$, recombinant apolipoprotein $\mathrm{E} 2$, apolipoprotein E3 and apolipoprotein E4). $k_{\text {ass }}$ is the mean of two values obtained by two methods (results). The equilibrium dissociation constant $K_{\mathrm{D}}$ is the report $k_{\text {diss }} / k_{\text {ass. }}$. 
Tab. 2 VLDL protein and apolipoprotein E content after enrichment with apolipoprotein $\mathrm{E}$

\begin{tabular}{|c|c|c|}
\hline VLDL & $\begin{array}{l}\text { Protein } \\
(\mathrm{g} / 1)\end{array}$ & $\begin{array}{l}\text { Apolipo- } \\
\text { protein } E \\
(\mathrm{mg} / \mathrm{l})\end{array}$ \\
\hline Apolipoprotein $\mathrm{E}$ deficient & 0.31 & 0 \\
\hline Recombinant apolipoprotein E2-enriched & 0.30 & 11.13 \\
\hline Recombinant apolipoprotein E3-enriched & 0.30 & 10.25 \\
\hline Recombinant apolipoprotein E4-enriched & 0.27 & 17.53 \\
\hline Human apolipoprotein E3-enriched & 0.30 & 37.20 \\
\hline
\end{tabular}

After incubation of the VLDL with the different apolipoprotein $\mathrm{E}$ isoforms (human apolipoprotein $\mathrm{E} 3$, recombinant apolipoprotein E2, apolipoprotein E3 and apolipoprotein E4), the amount of total proteins and the amount of apolipoprotein $\mathrm{E}$ were measured.

nant proteins and with human apolipoprotein E3. The different recombinant apolipoproteins $\mathrm{E}$ (recombinant apolipoprotein E2, recombinant apolipoprotein E3 and recombinant apolipoprotein E4) were equally efficient in association with VLDL that does not contain apolipoprotein E. Nevertheless, the ability of the recombinant proteins to associate to apolipoprotein E-deficient VLDL was less efficient than human plasma apolipoprotein E3 (tab. 2). After association, the molar ratio apolipoprotein E : apolipoprotein B48 in VLDL complex was estimated to be $0.6: 1$ for recombinant apolipoprotein E2 and recombinant apolipoprotein E3 and $1: 1$ for recombinant apolipoprotein E4. Each apolipoprotein E-VLDL complex was used in competition with ${ }^{125}$ I-labelled LDL for binding to the LDL receptor of J774 cells. Each VLDL particle competed efficiently (fig. 4), except for the recombinant apolipoprotein E2 complex and apolipoprotein E deficient VLDL, as expected.

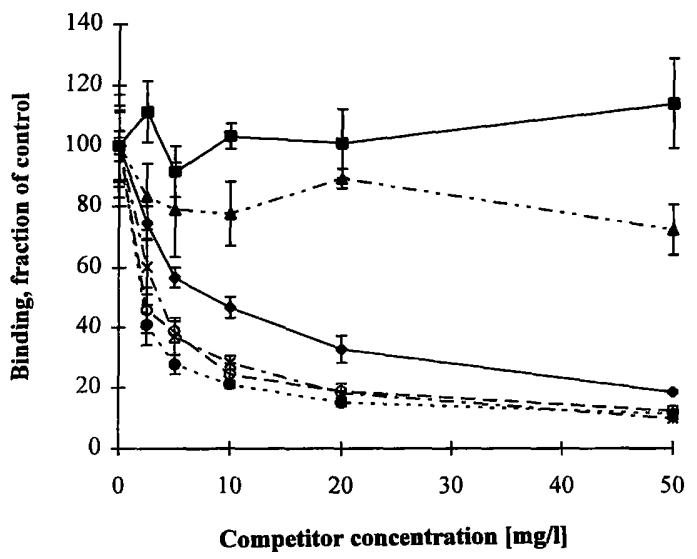

Fig. 4 Competition of $\left[{ }^{125} \mathrm{I}\right] \mathrm{LDL}$ with human plasma and recombinant apolipoprotein E enriched apolipoprotein E deficient VLDL using the J774 macrophage cell line. Competition was performed with human LDL $(-\bullet-)$, apolipoprotein E deficient-VLDL (-ם-), recombinant apolipoprotein E2-VLDL (-.....), recombinant apolipoprotein E3-VLDL (..-*-..), recombinant apolipoprotein E4-VLDL (......).

\section{Discussion}

Expression of human apolipoprotein E was achieved by using plasmid pARHS2, a very stable expression vector containing the parB locus. The parB locus mediates plasmid stabilization by post segregational killing of plasmid free cells (26). After isopropyl- $\beta$ - $D$-thiogalactopyranoside induction $100 \%$ of the cells still carried the pARHS2 plasmid containing the apolipoprotein E cDNA. This result indicates a high stability even when expression occurs.

Production was also achieved with the pRSETB plasmid, which showed a high instability in $E$. coli. The reasons for this instability are not clear because apolipoprotein $\mathrm{E}$ was not toxic for cells and we did not observe cell lysis during culture, as described by Vogel et al. (27). These authors used an expression vector containing the $\lambda \mathrm{P}_{\mathrm{L}}$ promoter regulated by the thermolabile cI repressor. Their system led to a cellular lysis associated with an intracellular accumulation of apolipoprotein $\mathrm{E}$, followed by a proteolytic destruction of apolipoprotein E $30 \mathrm{~min}$ after the induction. This cellular lysis is not a general characteristic of the expression vector, because this vector was used for the production of the human growth hormone and did not show this effect (27).

Monteilhet et al. (28) described another expression system in E. coli. Expressed sequences were under the control of the T7 promoter and allowed a production level of $15 \mathrm{mg} / \mathrm{l}$ of intact apolipoprotein E. Our system allows the production of $80 \mathrm{mg} / \mathrm{l}$ of apolipoprotein $\mathrm{E}$ while the yield of purification was of about $10 \mathrm{mg} / \mathrm{l}$ with a degree of purtiy $>95 \%$, as estimated by SDS-PAGE and gel scanning. This is similar to the level of production obtained with the baculovirus expression system (29), except that our system does not allow post-translational modifications of the protein. Purification of apolipoprotein $E$ routinely requires two chromatography steps (Heparin Sepharose and Sephacryl S300, or DEAE and Heparin Sepharose). Our system allows single step purification of fused proteins whose overall structural characteristics are similar to those of human plasma apolipoprotein $\mathrm{E}(20)$. The $\mathrm{Ni}^{2+}$-gel purification procedure is reproducible and faster than others previously described by purifying apolipoproteins $\mathrm{E}$ from different sources $(27,28)$.

The different experiments of characterization showed that the fusion-peptide did not interfere in the ability of the apolipoprotein $\mathrm{E}$ isoforms to bind to antibodies and to LDL receptor. The three monoclonal antibodies bind to the different apolipoprotein $\mathrm{E}$ isoforms with high affinity. Recombinant apolipoproteins $\mathrm{E}$ are somewhat less immunoreactive with the three antibodies than is purified plasma apolipoprotein $\mathrm{E}$, but the equilibrium dissociation constants $\left(K_{\mathrm{D}}\right)$ of the three antibodies with the three recombinant isoforms are similar, and comparable 
to that of human plasma apolipoprotein E3 (within 2 orders of magnitude). Thus, the presence of the $M_{\mathrm{r}}$ 40000 fusion-peptide did not significantly affect the accessibility of the three epitopes. Our results can be compared to those obtained recently by Raffai et al. (30), who examined by RIA and Surface Plasmon Resonance the immunoreactivity of three monoclonal antibodies (3H1, 1D7 and 2E8) with different variants of apolipoprotein $\mathrm{E}$ that were defective in LDL receptor binding capability. The authors described that all their variants (natural or recombinant) present a strong immunoreactivity with similar binding kinetics with the antibody $3 \mathrm{H} 1$. The equilibrium dissociation constants $\left(K_{\mathrm{D}}\right)$ are in the range of $2.4 \mathrm{nmol} / 1$ for natural apolipoprotein E3 and $5.4 \mathrm{nmol} / 1$ for natural apolipoprotein E2 ( $\operatorname{Arg}^{158} \rightarrow$ Cys). Our results are consistent with these. They show that the $K_{\mathrm{D}}$ constants are between $2.0 \mathrm{nmol} / 1$ for plasma apolipoprotein E3 and $3.6 \mathrm{nmol} / 1$ for recombinant apolipoprotein E3. Though the epitope of 1D7 is in the LDL receptor-binding domain, Riffai et al. show that apolipoprotein E2 (Arg ${ }^{158} \rightarrow$ Cys) presents a normal 1D7 reactivity $\left(K_{\mathrm{D}}=28 \mathrm{nmol} / \mathrm{l}\right)$, as compared to apolipoprotein E3 $\left(K_{\mathrm{D}}=19 \mathrm{nmol} / \mathrm{l}\right)$. Moreover, their recombinant variants, which present mutations in the receptor binding domain, clearly exhibit a lower capability to bind to 1D7 antibody than apolipoprotein E3 $\left(K_{\mathrm{D}}=60 \mathrm{nmol} / \mathrm{l}\right.$ and 73 $\mathrm{nmol} / \mathrm{l})$. Our recombinant proteins show close reactivity to those of natural variants, with $K_{\mathrm{D}}$ of recombinant apolipoprotein $\mathrm{E} 3=19.5 \mathrm{nmol} / \mathrm{l}, K_{\mathrm{D}}$ of recombinant apolipoprotein E2 $=16.5 \mathrm{nmol} / 1$ and $K_{\mathrm{D}}$ of recombinant apolipoprotein E4 $=19.3 \mathrm{nmol} / \mathrm{l}$. The differences observed between our different isoforms are minor compared to that existing with recombinant variants presenting real conformation changes.

Previously we have shown that the association of recombinant apolipoprotein E3 and E4 with lipids showed the same level of incorporation of the recombinant apolipoprotein $\mathrm{E}$ isoforms in di-myristoyl-phosphatidyl-choline particles and, using circular dichroism, the proportion of $\alpha$ helix, $\beta$ sheets and random coil was similar among the different apolipoproteins $\mathrm{E}$ in complexes

\section{References}

1. Mahley RW, Innerarity TL, Rall, Jr. SC, Weisgraber KH. Plasma lipoproteins: apolipoprotein structure and function. J Lipid Res 1984; 25:1277-94.

2. Zannis VI, Breslow J. Synthesis, intracellular processing and signal peptide of human apolipoprotein E. J Biol Chem 1984; 259:5495-9.

3. Mahley RW. Apolipoprotein E: cholesterol transport protein with expanding role in cell biology. Science $1988 ; 240$ :62230.

4. Pitas RE, Boyles JK, Lee SH, Foss D, Mahley RW. Astrocytes synthesize apolipoprotein $\mathrm{E}$ and metabolize apolipoprotein $\mathrm{E}$ containing lipoproteins. Biochim Biophys Acta 1987; 917:148-61.

5. Zannis VI, Just PW, Breslow JL. Human apolipoprotein E isoprotein subclasses are genetically determined. Am J Hum Genet 1981; 33:11-24.
(20). Here, we show that our recombinant proteins have the capability to associate with apolipoprotein Edeficient VLDL, nevertheless with a lower efficiency than plasma apolipoprotein E3, and to be active in lipid complexes in binding to the LDL receptor. The LDL receptor binding capability of the recombinant proteins was assessed using the $\mathbf{J} 774$ macrophage cell line. When reconstituted with mouse apolipoprotein Edeficient VLDL, recombinant apolipoprotein E3 and recombinant apolipoprotein $\mathrm{E} 4$ were as effective as human plasma apolipoprotein E3 in displacing the binding of ${ }^{125}$ I-labelled LDL, while recombinant apolipoprotein E2-VLDL complexes were not, as expected from the differential binding of the plasma apolipoprotein $\mathrm{E}$ isoforms to the LDL receptor (31). The lipid association capacity of our recombinant apolipoprotein $\mathrm{E}$ is clearly lower than that of human plasma apolipoprotein E3, probably due to the presence of the 42 amino acid fusion peptide. This extension could influence the interaction between $\mathrm{N}$ - and C-terminal domains, which composed apolipoprotein $\mathrm{E}$ and alter the lipids binding site. Nevertheless, the receptor binding site does not seem impaired.

In summary, the expression system described in this report allows the production of the three human apolipoprotein $\mathrm{E}$ isoforms, E2, E3 and E4 as recombinant fusion proteins whose structural and functional characteristics are close to their plasma counterparts. Thus, the pARHS2 vector expressing the apolipoprotein E cDNA in $E$. coli BL21(DE3) cells is a convenient system for obtaining large quantities of human apolipoprotein $\mathrm{E}$, particularly rare phenotypes.

\section{Acknowledgements}

The authors would like to thank Dr. Jean-Claude Mani, UMR CNRS 9921, Montpellier, France, for his precious assistance in Surface Plasmon Resonance, Mr Hans van der Boom for his technical assistance in LDL receptor binding studies, Dr. Yves Marcel and Dr. Ross Milne for the gift of the monoclonal antibodies. This work was supported by grants from the Région de Lorraine and from the European Community M \& T research program (MAT1CT 940046).

6. Utermann G, Steinmetz A, Weber W. Genetic control of human apolipoprotein $\mathrm{E}$ polymorphism: comparison of one- and two dimensional techniques of isoprotein analysis. Hum Genet 1982; 60:344-51.

7. Weisgraber KH, Roses AD, Strittmatter WJ. The role of apolipoprotein E in the nervous system. Curr Opin in Lipidol 1994; 5:110-6.

8. Takahashi S, Kawarabayasi Y, Nakai T, Sakai J, Yamamoto T. Rabbit very low density lipoprotein receptor: a low density lipoprotein receptor-like protein with distinct ligand specificity. Proc Natl Acad Sci USA 1992; 89:9252-6.

9. Bihain BE, Delplanque B, Khallou J, Chevreuil O, Troussard AA, Michel L, et al. Lipolysis-stimulated receptor: a newcomer on the lipoprotein research scene. Diabetes \& Metab $1995 ; 21: 121-6$ 
10. Kim DH, Iijima H, Goto K, Sakai J, Ishii H, Kim HJ, et al Human apolipoprotein E receptor 2. J Biol Chem 1996; 271:8373-80.

11. Lalazar A, Weisgraber $\mathrm{KH}$, Rall Jr SC, Giladi H, Innerarity TL, Levanon AZ, et al. Site-specific mutagenesis of human apolipoprotein E: receptor binding activity of variants with single amino acid substitutions. J Biol Chem 1988; 2633542-5.

12. Dong LM, Parkin S, Trakhanov SD, Rupp B, Simmons T, Arnold KS, et al. Novel mechanism for defective receptor binding of apolipoprotein E in type III hyperlipoproteinemia. Nature Struct Biol 1996; 3:718-22.

13. Davignon J, Gregg RE, Sing CF. Apolipoprotein E polymorphism and atherosclerosis. Arteriosclerosis 1988; 8:1-21.

14. van Bockxmeer FM. Apolipoprotein E and Alzheimer's. Nature $1995 ; 375: 285$.

15. Corder EH, Saunders AM, Strittmatter WJ, Schmechel DE, Gaskell PC, Small GW, et al. Gene dose of apolipoprotein E type 4 allele and the risk of Alzheimer's disease in late onset families. Science 1993; 261:921-3.

16. Poirier J. Apolipoprotein E in animal models of brain injury and in Alzheimer's disease. Trends Neurosci 1994; 12:52530.

17. Ohm TG, Kirca M, Bohl J, Schnarnagl H, Groß W, März W. Apolipoprotein $\mathrm{E}$ polymorphism influences not only cerebral senile plaque load but also Alzheimer-type neurofibrillary tangle formation. Neuroscience 1995; 66:583-7.

18. Schächter F, Faure-Delanef L, Guenot F, Rouger H, Frogel P, Lesueur-Ginot L, et al. Genetics associations with human longevity at the APOE and ACE loci. Nature Genet 1994. 6:29-32.

19. Corder EH, Saunders AM, Risch NJ, Strittmatter WJ, Schmechel DE, Gaskell PC, et al. Protective effect of apolipoprotein E type 2 allele for late onset Alzheimer's disease. Nature Genet 1994; 7:180-4.

20. Pillot T, Barbier A, Lozac'h K, Visvikis A, Rosseneu M, Vanderkerckhove J, et al. Single step purification of two functional apolipoprotein E variants hyperexpressed in Escherichia coli. Expr Purif 1996; 7:407-14.

21. Milne RW, Douste-Blazy Ph, Marcel YL. Characterization of monoclonal antibodies against human apolipoprotein $\mathrm{E}$. J Clin Invest $1981 ; 68: 111-7$.

22. Studier FW, Moffatt BA. Use of bacteriophage T7 RNA polymerase to direct selective high-level expression of cloned genes. J Mol Biol 1986; 189:13-30.
23. Dergunov AD, Aniskovich LP, Shuvaev VV. Affinity chromatography on heparin-sepharose under reducing conditions as a method of selective enrichment with individual isoforms of apolipoprotein E. Bull Exper Biol Med 1990; 110:42-5.

24. Chaiken I, Rosé S, Karlsson R. Analysis of macromolecular interactions using immobilized ligands. Anal Biochem 1992; 201:197-210.

25. Karlsson R, Michaelsson A, Mattsson L. Kinetic analysis of monoclonal antibody-antigen interactions with a new biosensor based analytical system. J Immunol Meth 1991; 145:299-310.

26. Gerdes, K. The parB (hok/sok) locus of plasmid R1: a general purpose plasmid stabilization system. Biotechnology 1988; 6:1402-5.

27. Vogel T, Weisgraber KH, Zeevi ML, Ben-Artzi H, Levanon AZ, Rall, Jr. SC, et al. Human apolipoprotein E expression in Escherichia coli: structural and functional identity of the bacterially produced protein with plasma apolipoprotein E. Proc Natl Acad Sci USA 1985; 82:8696-700.

28. Monteilhet C, Lachacinski N, Aggerbeck LP. Cytoplasmic and periplasmic production of human apolipoprotein $\mathrm{E}$ in Escherichia coli using natural and bacterial signal peptides. Gene 1992; 125:223-8.

29. Gretch DG, Sturley SL, Friesen PD, Beckage NE, Attie AD. Baculovirus-mediated expression of human apolipoprotein $\mathrm{E}$ in Manduca sexta larvae generates particles that bind to the low density lipoprotein receptor. Proc Natl Acad Sci USA $1991 ; 88: 8530-3$.

30. Riffai $R$, Maurice $R$, Weisgraber $K$, Innerarity $T$, Wang $X$, MacKenzie $R$, et al. Molecular characterization of two monoclonal antibodies specific for the LDL receptor-binding site of human apolipoprotein E. J Lipid Res 1995; 36:1905-18.

31. Weisgraber KH, Innerarity TL, Mahley RW. Abnormal lipoprotein receptor-binding activity of the human $E$ apoprotein due to cystein-arginine interchange at a single site. J Biol Chem $1982 ; 257: 2518-21$.

\section{Received February II/May 23, 1997}

Corresponding author: Professor Dr. Gérard Siest, Centre du Médicament, Université de Nancy $1 \mathrm{H}$. Poincaré, URA CNRS 597, 30, Rue Lionnois, F-54000 Nancy, France 
